\title{
New Thoughts on Leaders in the New Era
}

\author{
Xuzhi Zhao \\ Shanghai University of Management, Shanghai, China \\ Email: 907451216@qq.com
}

How to cite this paper: Zhao, X.Z. (2019) New Thoughts on Leaders in the New Era. Open Access Library Journal, 6: e5213. https://doi.org/10.4236/oalib.1105213

Received: January 28, 2019

Accepted: February 16, 2019

Published: February 19, 2019

Copyright $\odot 2019$ by author(s) and Open Access Library Inc.

This work is licensed under the Creative Commons Attribution International License (CC BY 4.0).

http://creativecommons.org/licenses/by/4.0/

\begin{abstract}
The new era requires vigorous selection of cadres who dare to act as courageous and courageous leaders. Leaders must assume the new mission entrusted by the new era and must have the leadership and art of knowing others. Knowing people and being good and knowing is the premise, and good deeds are the key. Knowing people's good deeds is of great significance to the development of a unit's cause. Leaders must overcome many problems in selecting and employing people and adopt positive and effective methods and measures to achieve good deeds.
\end{abstract}

\section{Subject Areas}

Politics

\section{Keywords}

New Era, Leader, Knowing Others, New Thinking

\section{Introduction}

In May 2018, the "Opinions on Further Encouraging the New Era of New Cadres, New Roles, and New Actions" issued by the General Office of the Central Committee of the Communist Party of China clearly stated that we must adhere to Xi Jinping's new era of socialist ideology with socialism with Chinese characteristics and vigorously select and dare to be responsible. A cadre who has the courage to act, is good at acting, and has outstanding performance. Therefore, if leaders are to take on the new mission entrusted by the new era, they must grasp the way of employing people with good deeds.

\section{The Meaning of Knowing People}

As the name suggests, the first thing to know is to know people. Knowing people is to understand people in all aspects, mainly referring to all-round investigation, 
identification and selection of people. To be good at doing is to be good at using people. It means to use people properly, to be suitable for people, and to use others. Knowing people's good responsibilities is to carefully and rigorously examine cadres, accurately and completely understand cadres, and arrange each cadre to an appropriate position according to the cadres' own strengths, weaknesses, disadvantages, and advantages, so that they can fully engage themselves. The advantages, the ability to display, the pleasure in the work, the maximum potential of their own expertise, and the maximum value of work. This is the highest level of employment and the necessary leadership art for leaders.

\section{The Importance of Leaders in Knowing others}

"Shang Xian, the political foundation is also", "for the political, Mo is the first to use people." The Communist Party of China has always attached great importance to the election of talents. It has always been considered that the selection and employment of people is a key and fundamental issue that affects the cause of the party and the people. The first thing to do is to use people. Comrade Mao Zedong said: "The responsibility of the leader comes down to two main things: the idea and the use of cadres." He also said: "After the political line is determined, the cadre is the factor of decision [1]." If the leader can't know how to be good, it is a great waste of talent itself, and it is a great loss to the development of the cause.

Comrade Xi Jinping said in his speech at the National Organizational Work Conference: "With a sage, the sages are full of talents, and seeing the sages and sorrows will become a common practice. Whoever chooses the wind vane, what kind of cadre style, and even what kind of party Party committees and organizations at all levels must uphold the principle of party-management cadres, adhere to the correct orientation of employing people, adhere to both ability and ethics, and take morality first, and strive to be able to use talents, use them for the time, know people and do their best, and make the best of their talents. Good cadres are discovered in time and used reasonably [2].

The main reason why Han Gaozu Liu Bang obtained the world is his knowledge and good deeds. According to the historical records: GaoZuyu: "In the midst of the tactics of the husband, the victory is thousands of miles away. I am not as good as the quilt; the town, the people, the people, the graciousness, the endless food, I am not as good as Xiao He; even the people of the hundred, the battle must Win, attack must take, I am not as good as Han Xin. All three are outstanding, I can use it, so the world is also taken, Xiang Yu has a fan increase and can not be used, this is why I am also [3].

There is a Qinzhitang in the second hall of Neixiang County, and the "Qinzhi" comes from "Lv's Spring and Autumn.Chaxian": "The scorpion is a single father, playing the piano, and he is not a single father. Take the stars out, take the stars into, do not live day and night, to the dear, and the single father is also ruled. The witch and the horse asked him why he was in the scorpion. The scorpion 
said: "I am a person, the child is the arbitrage. The person who is willing to work hard, the person who is willing to leave [4].

After comparison, we can see that the scorpion scorpion and the sorcerer's period are good officials with virtues and talents, and the people who love the people, and the tactics of the scorpion singer and the singer are better than the sorcerer's affairs.

On the other hand, if the leader can't know how to be good, the harm of choosing the wrong one is the same. People often say that a soldier is a raging bear, and that an incompetent leader will lead a unit to astray, which will bring immeasurable losses to the whole cause, and will also have a negative impact on the entire cadre team. Cadres lose their integrity to leaders and organizations, causing negative factors such as slack work, overstaffing, and complaints. This state of work will seriously affect career development. When talking about the selection of talents, General Secretary Xi Jinping pointed out: "When the knowledge is not deep and the people are not accurate, there will often be misappropriation and misuse of the employer." Wei Yuan, a politician and thinker of the Qing Dynasty, puts forward that "the shortcomings are not known, and the length of the people is unknown." I don't know how short people are, but I don't know if people are short-term, they can't use people, they can't teach people. This is also the truth.

\section{The Leader Is Easy to Use Problems}

We put forward career development in practical work. The importance of talents is self-evident. When it comes to talents, we will say that we must know people to be good, to choose talents, to be talented, to select talents with ethics, and so on. However, the game of human sentiment and jurisprudence that has been inherited from the past dynasties in China has existed. The leaders have always been plagued by human factors in the selection and employment of people. It is prone to not to act, not to act, not to know ourselves, to know people, to be crony, to fight for power. Money, rights trading and other phenomena. In addition to this, there are the following issues.

1) The selection of recommended conditions violates the original intention. In the selection of cadres, attention is paid to setting conditions and rules such as gender, age, education, rank, etc., and the name is optimized to optimize the cadre team structure. However, the level of management is not directly proportional to these conditions. condition. In order to achieve the statistics of optimizing the structure of the cadre team, it has limited the outstanding cadres with true morality and talents to stand out from the crowd, completely deviating from the initial intention of declining talents.

2) The selection process is subject to discussion. Once upon a time, when leaders and organizations selected cadres, they were keen to adopt a competitive speech format instead of a serious cadre selection recommendation process. Based on external experts and leaders, they could judge the merits, talents, dili- 
gence and performance of the contestants. How much is cheap, relying on a few minutes of speech to decide who can be promoted, but also known as open, fair and just. The good cadres who have both true morality and ability are not told, they are diligent and down-to-earth. In this way, the leader has shirked personal responsibility, avoided contradictions, and cooled the hearts of honest people. Such selection is seriously irresponsible to the cause of the party.

3) The selection recommendation principle is not reasonable. In order to attract and retain highly educated talents, leaders assign positions to highly educated people regardless of whether the position is suitable for these people. In this way, all highly educated personnel must compare positions, otherwise they will not pay attention to them, resulting in a vicious circle. If the person's post is uncomfortable and affects the work of the unit, it will delay the development of personal career and cause waste of human resources.

4) The selection and inspection mechanism needs to be sound. The selected person is recommended by the organization department and the leader. Then, the scope of the referee's investigation, the inspection team is selected by the leadership and the organization department, and both the rule maker and the rule performer are actually making themselves The selected team said that the cadres I recommended would not work. Will the leaders self-denial? Therefore, Comrade Xi Jinping said: "The understanding of cadres cannot stay in the feelings and impressions. It is necessary to improve the investigation mechanism and methods, and to understand in depth through multiple channels, multiple levels and multiple aspects."

\section{How Can Leaders Be Knowledgeable and Responsible}

1) Knowing people is the prerequisite for good responsibilities. Knowing people is a must-have for leaders. Only a discerning leader can identify talents and discover talents. The ancients said: There is Bole in the world, and then there are thousands of horses. Maxima often has, and Bole does not often. Fully explain the difficulty of knowing people, Bole is difficult. How to know people deserves our deep thought. Bole is a horse, and the leader knows how to have a way. Zhuge Liang knows the seven laws of the people: "When you ask the right and wrong, you can see the ambition; the poor thinks about it by arguing; the confession is based on the strategy and the knowledge; the sorrow is to look at its sorrow; And to observe its nature; to look at its advantages in the future; to observe its letter [5].

People are both-sided, so knowing people is a leader who needs to work hard. "The Scorpion" said: "The mouth can speak, the body can do it, the national treasure is also; the mouth can not speak, the body can do it, the state device is also; the mouth can speak, the body can not do, the national use also; Good, evil, and the national demon [6]. Of course, the leaders of the new era need to distinguish their own situations in practical work and subtleties, and use the modern scientific principles of leadership to conduct long-term inspections and tests, 
and sum up the mechanism for selecting and employing people.

$\mathrm{Xi}$ Jinping asked the party committee to organize the department: "Inspect and identify the cadres, the Kung Fu should be in the usual time, and pay attention to the critical moments, the key moments. After the thousands of songs and then Xiaosheng, watch the sword and then recognize the device. The performance of the cadres is in practice, the cadres are famous in the folk. More To the cadres at the grassroots level, and to learn more about the cadres in the word-of-mouth of the village, it is necessary to look at the virtues in major events, and to observe the virtues in the small sections [2].

2) Good office is the key to knowing people. "A person can only do his best if he is in the position where he can best use his talents [7]." Liu Han of the Western Han Dynasty said in the "Huainanzi Master Training": "The employer of the sage is also the wood, the big one thinks that the boat hangs the beam, the small one thinks that the wedge [8]". Therefore, the leader must use the person, according to the actual needs of the job, to adapt to the person, to choose people, can not simply assign the position as a treatment.

Despite the historical differences in Song Jiang in the "Water Margin", we have to admit that Song Jiang does have a set of people. In the face of Liangshan heroes, the one hundred and eight men will be different in personality, complex in composition, unruly and different in character; face the contradictory focus of the rights and interests of all people. Song Jiang can clearly divide the work according to the characteristics and personality of 108 heroes, optimize the allocation of resources, handle the ease, and unite them for my use, and everyone has no complaints. It shows that Song Jiang has its own personality charm, but also has the superb leadership art and leadership wisdom of knowing others. Therefore, the key issue for us is not to use this person but not to use that person, but to make each employee assign the most appropriate position according to their own interests and specialties, so that they can play in the right position. The biggest feature is to discover its greatest potential and create maximum value.

3) A new type of think tank should be set up to select and employ leaders, and a sound personnel mechanism should be established. Leaders must be based on both ability and political integrity, with morality as the first priority, but also adhere to the principle of arbitrariness, meritocracy, and conviction, service for the people, diligence and pragmatism, daring to take responsibility, and integrity as the standard and criteria for the correct selection and employment. Different types of new talent think tanks. As a leader, the new think tank is an important support for decision-making, and it is targeted and targeted. This allows the leader's decision time to be effectively saved, thereby improving the efficiency and accuracy of the leader's selection and employment.

In short, the leader must also do love, ritual, and talent in the process of employing people. To accommodate people, tolerate people and tolerate people. There is no gold in the red, no one is perfect, "the gentleman uses people as a device, and each takes his own strength." Only by focusing on the strengths and 
strengths of people can leaders discover talents, use talents, and retain talents. The Ming Dynasty GuYuxie Shi Yun: "The horse can be an adventure; the plowing field is not as good as the cow. The car can carry the weight, crossing the river is not as good as the boat." It can be seen that the use of people, the shortness of avoiding people, and even short, is a brilliant art of employing people. I hope that more leaders can master and skillfully use the leadership art of knowing others.

\section{Conflicts of Interest}

The author declares no conflicts of interest regarding the publication of this paper.

\section{References}

[1] "The Position of the Communist Party of China in the National War" in the Second Volume of Selected Works of Mao Zedong (October 14, 1938) "Public Policy".

[2] Xi, J.P. (2011) Xi Jinping's Speech at the National Organization Work Conference.

[3] Si, M.Q. Historical Records Gaozu Ben Ji Eight.

[4] Lu, B.W. Lv's Spring and Autumn Chaxian.

[5] Zhuge, L. The Seven Laws of Knowing People.

[6] Xunzi. The Roughly.

[7] Roger Falk. Talking about Enterprise Management.

[8] Liu, X. Huainanzi-Master Training. 